Makale Geliş | Received: 09.08.2018

Makale Kabul | Accepted: 16.08.2018

DOI: $10.18795 /$ gumusmaviatlas.452309

Mavi Atlas, 6(2)/2018: 95-117.

Araştırma Makalesi | Research Article

\author{
Büșra COȘANAY \\ Arş. Gör. | Res. Assist. \\ Artvin Çoruh Üniversitesi, Fen-Edebiyat Fakültesi, Felsefe Bölümü, Artvin, TR \\ Artvin Çoruh University, Faculty of Arts and Sciences, Department of Philosophy, Artvin, TR \\ ORCID: 0000-0002-2918-6131 \\ busracosanay@artvin.edu.tr
}

\title{
Muhammed İkbâl'in Benlik Felsefesi
}

Öz

Muhammed İkbâl'in düşüncesinde Tanrı ve evrene ilişkin bir açılama yapabilmek için onun benlik felsefesini bilmek hayati önem taşır. Çünkü o, Tanrı ve evren söz konusu olduğunda tüm açıklamalarını ben felsefesi üzerinden yapar. Onun benlik felsefesinde Tanrı ve evrendeki her şey bir bene sahiptir. Evrendeki işleyişi anlamak ve varlığa ilişkin bir şeyler söylemek için benin mahiyeti, işlevleri, salahiyetleri ve sınırlarının açıklanması gerekir. Çalışmamızda benin mahiyeti, insanın şuurlu tecrübesinden hareketle sahip olduğu eylemler sistemi olarak tanımlanmış olup benin insanda tecrübeler yoluyla açığa çıktığı, insanı sahip olabileceği en yüksek noktaya götürebileceği İkbâl'den alınan şiir ve düz yazı örnekleriyle açıklanmıştır. Aynı zamanda insana özgürlüğünü ve Tanrı'yla iletişim imkânını vermek bakımından benin metafiziksel yönü açıklanmaya çalışılmıştır.

Anahtar Kelimeler: Muhammed İkbâl, Benlik Felsefesi, Tanrı, Evren, Tasavvuf.

\section{The Self-Philosophy of Muhammad Iqbal}

\begin{abstract}
In the thinking of Muhammad Iqbal, it is vital to know his self-philosophy in order to make an account of God and the universe. Because he make all their explanations through self-philosophy when God and the universe are concerned. God and everything in the universe has an ego in his self-philosophy. It needs to explain the nature, functions, capabilities and boundaries of ego in order to understand what is running of the universe and to say something about it. In our work, the nature of ego is defined as a system of actions in which a person has act of conscious experience. It's explained by examples of poetry and plain writing from Iqbal that it can be brought to the highest point that person can have, which ego has come to open in person through experiences. At the same time it has been tried to explain the metaphysical aspect of ego in terms of freedom and communication with God.
\end{abstract}

Keywords: Muhammad Iqbal, Self-Philosophy, God, Universe, Sufism.

\section{Giriş}

Muhammed İkbâl'in temel düşüncesini, modern dönemde Whitehead'den aldığı, Kur'ân-ı Kerîm ve tasavvuf anlayışı ile temellendirdiği dinamizm anlayışı oluşturur. O, Tanrı-evren ilişkisi söz konusu olduğunda Kur'ân'ın öne sürdüğü dinamik hayatı yani amelî hayatı haklı görür. Bu sebeple İkbâl, dinamizmi reddeden ve oluşu yadsıyan her türlü düşüncenin karşısında yer alır ve Aristoteles'ten beri süregelen statik evren anlayışını, evreni mekanizme hapsettiği gerekçesi ile kabul etmez. İkbâl'e göre bir 
düşüncenin tam manâsıyla anlaşılabilmesi için Tanrı tasavvuru gereklidir. Çünkü ona göre, yaratıcısıyla ilişkilendirilmeyen hiçbir bilgi tam anlamıyla doğru sayılmaz. İkbâl, duyu tecrübelerimizin verilerine güvendiğimiz kadar dînî tecrübelerimize de güvenmemiz gerektiğini düşünür ve doğa bilimlerinin yanına mistisizmi de bir bilgi kaynağı olarak koyar. Ona göre, Kur'ân'da anlatılan dinamizm düşüncesi, modern bilimle birlikte kanıtlanmıştır. Mistik bilgi ise bize hayatı anlamlandırmayı ve doğa bilimleriyle elde edemediğimiz gerçeklik imkânını sunar.

İkbâl, Tanrı ve evreni birbirinden bağımsız iki varlık olarak görmez; o, bu anlamda Tanrı'nın evrende aşkın olduğu düşüncesine karşı çıkar. Çünkü ona göre evrendeki her şey yaratıcısına organik bir bağla bağlıdır. Dolayısıyla evrendeki tüm olaylar ve varolan şeyler Tanrı'nın bir açılımıdır. Tanrı, diğer tüm şeylere göre sonsuz ve sınırsızdır fakat bu sonsuzluk zaman ve mekân bakımından değil yoğunluk bakımındandır. Onun her bir açılımı evrende yeni bir yaradılışı gerçekleştirir.

“İkbâl'e göre hakîkat, bir ruhtur ve bu da benliktir. Klasik İslâm filozoflarının kullandığı nefs kavramına karşılık gelen bu kavram, İkbâl'in eserlerinde ene, hûdî ve ego olarak kullanılmıştır” (Aydın, 2000: 119). İkbâl'in benlik felsefesi, evrende varolan her şeyde, Tanrı'dan atoma kadar, bir benlik bulunduğunu ileri sürer. Tanrı Mutlak Ben'dir yani sonsuz bendir ve diğer tüm varlıklar da sonlu benliğe sahiptir. Tanrı Mutlak Ben olduğu için diğer tüm benler varlığını mutlak olandan almıştır ve yaratıcısına organik bir bağla bağlıdır. Tanrı ise yaratıcı olması bakımından sürekli faal bulunur.

İkbâl, vahdet-i vücûd düşüncesinden hatırlayacağımız üzere, sonlu benlerin Mutlak Ben’de kendini yok ettiği düşüncesini kabul etmez. Onlar, Mutlak Ben karşısında kendi benliğini ve potansiyellerini bilir. Benliğin bu anlamda, en önemli işi faal yani etken bulunmaktır. Eğer ben eylemsizliğe kapılırsa yok olur bu nedenle o, her an faal olan Tanrı'ya ulaşmak ve ebedileşmek için eylemde bulunmalıdır. Sonlu benler, kendi benliğini geliştirmeli ve bu sayede Mutlak Ben’le bir temas kurmayı amaç edinmelidir. İkbâl, Mutlak Ben’e en fazla yaklaşan bireyin en fazla birey olduğunu ve kemâle erdiğini düşünür. Mutlak Ben’e ulaşmanın yolu ise, ona göre bir mürşide bağlanmak ve bu yolla benliği güçlendirmektir.

İkbâl'in hakîkat anlayışında tasavvuf düstûru önemli bir yer tutar. Çünkü o, hakîkate ulaşmanın bir yolunu mistik tecrübeye bağlar. Yani onun düşüncesinde insan, bir an için Mutlak Hakîkat'i deneyimleyebilir; bu ise yalnızca gönüldeki aşk bağlamıyla mümkündür. İkbâl, düşüncenin Hakîkat'e yalnızca akılla ulaşılabileceğini düşünen Batı 
düşüncesini eleştirerek tasavvufi manâda bir sezgi yani feyz olmadan asla gerçeğe ulaşılamayacağını söyler. Ego ve aşk arasında çok yakın bir ilgi kuran İkbâl, temelde benliği güçlendirmenin önemini vurgularken, bunun için mutlak hakîkate duyulan aşkın gerekliliğine de dikkat çeker. Onun tasavvuf anlayışı, benliği zayıflatan veya yok eden bir anlayış değildir. Aksine bir müslümanın her dâim kendi gücünün ve potansiyelinin farkında olması ve insanların benliğini güçlendirerek sürekli amellerde bulunması gerektiğini düşünür.

Ona göre, evrendeki hareket ve dinamizm sürekli yaradılışın bir yansımasıdır. $\mathrm{Bu}$ nedenle insanlar da buna paralel olarak dinamik yapının bir parçasıdır. Kur'ân da insanlara amelleri emreder ve ancak bu ameller doğrultusunda onları bir değere sahip k1lar.

\section{Benliğin Mahiyeti}

Benlik kavramı, kendi başına sı̆̆ bir konu olmayıp hemen her konuyu içeren bir genişliğe sahiptir. Onun izini pek çok filozofta sürebiliriz. Sofist, 'insan her şeyin ölçüsüdür' derken bilen özneyi merkezileştirir. Sokrates, 'kendini bil' sözünü bir buyruk hâline getirirken, ben bilgisinin önceliğine işaret eder. 'Kendini bilen Rabbini bilir' sözü ben bilgisini Tanrı'yı bilmenin yollarından biri olarak görür. Hallâc-1 Mansur'dan Mevlâna'ya uzanan ve oradan günümüze doğru gelen tasavvuf çizgisinde beşeri benliğin mahiyeti ve ilâhi benlikle olan ontolojik ilişkisi üzerinde durulur. Pascal, evrenin derinliği karşısında kendi iç derinliğinden hayranlıkla söz eder. Kierkegaard, ruhun ve bedenin, sonlunun ve sonsuzun, özgürlük ve zorunluluğun sentezi olarak tanımladığ benliği, varoluşun anlamı ve en üst telosu olarak görür. (Taşdelen, 2013: 2728). Kısacası varlığın hakîkati ve içselliğini, varoluşa dair tüm düşüncelerin merkezini benlik kavramı oluşturur. Anlama ve yorumlama insandan bağımsız olamaz dolayısıyla bir yargıda bulunabilmek için insanın insana veya insanın kendine dönmesi gerekir. Sokratik görüşte olduğu gibi, hakîkat insana sunulmaz, onun içindedir. Aynı zamanda her insan kendisinin orta noktasıdır ve kendi bilgisi Tanrı bilgisi olduğu için bütün dünya yalnızca o insanda odaklanır (Kierkegaard, 2017a: 3).

Ben kavramı, insanda temel olarak psikolojik, metafizik ve ahlâki boyutta anlam kazanır. Psikolojide ben, ego olarak karşı1ık bulur ve "Freud, ben’i (ego) id ile süperego arasında gerçeklik ilkesine göre hareket eden düzenleyici olarak belirler. Jung’a göre ego kavramı, farkındalığın merkezini oluşturur. Ruhsal yapının bilinçli düşünceler, duygular, anılar ve algılardan oluşan ve kişiye kalıcı ve sürekli bir kimlik duygusu 
veren parçasıdır” (İnanç; Yerlikaya, 2012: 21, 70). Ego, nefsin bitmek bilmeyen istekleri ile ahlâki normlar arasındaki dengeyi sağlayan aracı gibi gözükmektedir.

İkbâl benliğin psikolojik niteliğine modern psikolog W. James'i eleştirerek değinir; W. James’e göre benlik, kişisel duygulardan müteşekkildir ve bu itibarla, düşünce sisteminin bir bölümünü oluşturur. Düşüncenin her titreyişi, ister mevcut ister geçmiş olsun, bilen ve hatırlayan bölünmez bir birliktir. Mevcut titreyişin geçici titreyişi, daha sonraki titreyişin de mevcut titreyişi tasarruf etmesi olayı "benlik"tir (İkbâl, 2014: 123). İkbâl'e göre, W. James'in şuurla ilgili bu teorisi benliğin niteliğini açıklamaktan acizdir. Çünkü ona göre, düşüncelerin geliş ve gidişi devamlılıktan yoksundur. Bir düşünce veya fikir aklımıza gelince ikincisi tamamıyla kaybolup gider. Böyle bir durumda aklımızdan geçen bir fikir, daha doğrusu, geri dönmez bir şekilde kaybolup gitmiş geçici bir düşünce, o sırada kafamızda mevcut olan düşünce tarafından nasıl bilinip benimsenebilir? Benlik, bir gerginlik durumudur ve kendi tecrübesiyle şekillenir. Ben'i mekânda bir şey veya zamana ait düzen içinde bir takım tecrübeler olarak idrak edemezsiniz. Ben'i hükümlerimle, iradi tutumlarımla, amaçlarımla ve emellerimle yorumlamalı, anlamalı ve takdir etmelisiniz (İkbâl, 2014: 123-125). Ben, nefsi durumların emsalsiz, eşsiz ve birbirine olan bağlılığıdır (İkbâl, 2014: 121).

İkbâl'in benlik görüşü, psikolojik değil metafizik ve ahlâk düşüncesinin bir ürünüdür. İkbâl'in metafiziğinde atomdan insana kadar bütün varlık mertebelerinde bir ben vardır; Tanrı ise, Mutlak Ben (ene)'dir.

Mutlak Ben, zât-1 ilahiyi; diğer benler beşeri benlikleri temsil eder. Burada asıl olan, aşkınlaşmaya tâbi olan beşeri benliktir. Mutlak benlik, aklın kavrayış alanının dışında bulunur. Onunla akıl yoluyla değil, gönül yoluyla temasa geçilir. Tanrı'ya giden yol, bir sevgi ve aşk yoludur. Mutlak Benlik, tüm varlığın çıkış ve erim noktası olarak var edici ve var kılıcı ilkeyi gösterir. Onunla en iyi sevgi ve iman ile, bir gönül yaşantısı ile iletişim kurulabilir. Bu iletişim ve temas, bütün benliklerin kaynağı ve imkânıdır (Taşdelen, 2013: 33).

İkbâl'in benlik anlayışında, nefsini geliştirebilecek en yetkin varlık insandır. İnsan, kendi içindeki iradesi ve iç yetenekleri sayesinde bunu yapabilir ve bu sayede o, Mutlak Ene'ye diğer varlık mertebelerinden daha yakın durur. (Aydın, 2000: 157).

"Varlığın şekli, benliğin eserlerindendir. Her gördügün şey, benliğin sirlarındandır.

Benlik, kendi kendini uyandırınca bu vehim ve zan âlemini zuhura getirdi. 
Onun zatında yüzlerce cihan gizlidir. Ondan gayrısı, onun ispatından meydana gelmiştir.

Kendini göstermek benliğin huyudur. Her zerrede uyuyan, gizlenen benlik kudretidir.

Benlik, hayat kudretini bir araya topladı mı hayat ırmağından muazzam bir deniz vücuda getirir” (İkbâl, 2005: 32-34).

İkbâl'e göre, âlemin nizamının aslı benliktir. O, her varlıkta bulunur ve kendini açığa çıkarma kuvvesine sahiptir, ancak benliğin ispatıyla ondan gayrı olan anlaşılabilir. Çünkü her şeyde bulunan benlik kendini farklı şekillerde açığa çıkarır ve her şey onun eseridir. Benlik kendini güçlendirmesi ölçüsünce Mutlak Ben’e daha yakın olur. Bu, onun değersiz varlığına değer katar ve sonlunun sonsuza doğru hareketini imler.

Mademki âlemin hayatı, benlik kudretindedir; o hâlde o ne kadar metin ve muhkem olursa hayat da o derece metin olur.

Katre, benlik sözünü ezber ederse değersiz varlığını inci hâline getirir.

Dağ, benlikten geçti mi sahra olur. Denizin coşkunluğundan şikâyet eder (İkbâl, 2005: 34).

İkbâl, ben olmaktan vazgeçen bir varlığın, omurgası alınan bir canlı gibi ayakta duramayacağını, bir dağın sahraya dönüşmesi gibi yere serileceğini söyler. Benliği yadsımak, son kertede kendi varlığını yadsımak olacaktır (Taşdelen, 2013: 27).

İkbâl, Kur'ân-ı Kerîm'den hareketle insanın yaratılmış en iyi yaratık olduğunu ileri sürer. Onun düşünce ve irfan dünyasının kalkış noktası da, zirve noktası da insandır. Her şeyin merkezine oturttuğu insanı tanıyarak, gerçeklerini fark etmeye ve bu farkındalığı diğer insanlara da aktarmaya çalışmıştır. Bu yolla, ideal bir insan ya da insan-1 kâmil ideasını ortaya koyan İkbâl, sonsuz bir mucizeler zincirini teşkil eden insanoğlunu her dem diri tutmaya çalışmıştır. Çünkü kâmil insan, insanlık kervanını kurtuluşa erdirebilecek önderdir (İkbâl, 2015: 26-27).

İkbâl, İslâm'da Dini Düşüncenin Yeniden Teşekkülü'nde insan şahsiyetinin merkezini teşkil eden insanın şuur birliğinin, İslâm düşüncesi tarihinde dikkate değer bir konu olarak ele alınmadığı için yakınır. İnsanın ruh ve maddeden oluştuğunu söyleyen düalist anlayışın eksik kaldığını, insanın iç tecrübesinin birliğinin yalnızca tasavvuf düşüncesi tarafından anlaşıldığını söyler (İkbâl, 2014: 116). 
İnsanoğlu dediğin, bir var bir yok olma büyüsüdür,

Tanrı sırrıdır; kelimeler kifayetsiz ifade etmeye.

Zaman, ezel sabahından beri yol kat etmekte,

Fakat onun bu koşturması yetmedi insanı eskitmeye.

Aklın karışmazsa sana açıkça söyleyeyim:

İnsanoğlunun varlığı ne ruh ne de bedendir (İkbâl, 2013a: 76).

İkbâl, benliğin bir başka deyişle egonun, gerçek niteliğinin ne olduğuna dair bir takım açıklamalar yapmaya çalışır. Ona göre insan, evrende Tanrı'nın eli, kolu gibidir. Eğer insan benliğini güçlendirir ve kemâl derecesine ererse zamandan tasarruf etmeye başlar. Artık zamânın hükmettiği değil zamâna hükmeden rolünü üstlenir. Bu nedenle insanı, ruh-beden ikilisi kadar basit düşünmemek gerektiğini söyler.

Ego, bizim nefsi addettiğimiz durumlarda kendini ortaya koyar. Ne var ki, nefsi durumlar müstakil veya bağımsız bir varlığa sahip değildirler. Bunlar birbirinin anlamını ifade eder ve birbirini sarar. Bunlar, nefis (zihin) olarak tabir ettiğimiz karmaşık bir bütünün davranış ve safhalarıdır. Ayrıca, bu birbirine bağlı durumlar veya olayların organik birliği kendine özgü bir birliktir (İkbâl, 2014: 119). İnsanın şuur birliği, mental davranışlarının birliğidir. İnsanın düşüncesi, gösterdiği eylemlerle paraleldir ve kendine özgü organik bir bütünlük içindedir. İkbâl'in organizm fikri, modern dönemde Whitehead'de yankısını bulur. Whitehead'e göre, “evrende bütün var olanlar arasında organik bir bağ bulunmaktadır. Bir şey öteki şeylerden tamamıyla soyutlanamaz. Her bil-fiil şey, öteki bil-fiil şeyleri kavrar. Kendinden önce gelenleri kavrar; kendisinden sonra gelenlerce kavranır. Bunun sonucu olarak bir varlığın ötekini duyması, ötekinde objektifleşmesi mümkün olur" (Whitehead, 1929: 66). Whitehead'in organizm fikrini benimseyen İkbâl için de durum aynıdır. Şeyler arasında iç içe geçmişlik ve bütünlüklü bir bağ bulunur.

$\mathrm{Bu}$ bütünlük egoyu ne maddi bir varlık olarak tek bir mekâna bağlı kılar ne de doğa olaylarının zamâna tâbi olması gibi zamâna tâbi olur. Benlik, birden fazla mekânda bulunabilir tıpkı rüyada iken farklı mekânlarda bulunması gibi ve benliğin zaman süreci mekân içinde üslenir ve kendine özgüdür. Benlik, geçmiş ve geleceğe bağlıdır fakat bir tabiat olayı gibi değil çünkü gerçek zaman süreci şuursaldır ve benliğe bağlıdır.

Benlik birliğinin diğer bir önemli özelliği, her benliğin yegâneliğini meydana koyan esas yalnızlık durumudur (İkbâl, 2014: 121). İnsan şuuru bir birlik olduğu için 
belli bir mantıkî hükme ulaşmak için bütün kıyasların aynı zihinde yapılması gerekir. Yani iki öncülden birini ben ileri sürerken ikincisini başka bir zihnin ileri sürmesi aynı mantıkî kabule götürmez. O nedenle, bir yeri tanımak için başkasının tecrübesine değil kendi tecrübelerimize başvururuz bu ise bizim şuur birliğimizin ve zihnî durumlarımızın birbirine bağl1lı̆̆ını gösterir.

İkbâl, benliği nefsi durumlardan ayrı, sade, bölünmez ve değişmez ruhani bir cevher olarak kabul eden başta İmam-1 Gazâli olmak üzere İslâm ilahiyat ekolünün görüşünü eleştirir. Bizim şuurlu tecrübemiz, ruh özünün özellikleri arasında sayılamaz. Ayrıca ruhun varlığını ister şuurlu tecrübelerimizin bir izahı, ister ölmezliğin temeli olarak alalım bunun ne psikolojiye ne de metafizik görüşe yararı vardır. Ona göre, Kant'ın bölünmez şeyin şiddetli bir durum gibi yavaş yavaş hiçlik içinde kaybolması veya birden bire yok olması teorisi de psikolojiye herhangi bir katkıda bulunmaz. İlk önce maddi bir cismin tartısını o cismin özelliği saymak ne kadar güç ise, bizim şuurlu tecrübemizin unsurlarını da bir ruh özünün özellikleri addetmek öylece güçtür. Gözlemin bize gösterdiğine göre, tecrübe, herhangi bir şeyi vurgulayan ve kanıtlayan fiillerdir ve bu bakımdan kendilerine mahsus bir varlığa sahiptirler (İkbâl, 2014: 121122).

İkbâl, şuurlu tecrübeden benliğin manevi bir cevher olduğu yargısının belli olamayacağını söyler. Fakat yine de şuurlu tecrübemizin açıklanması bizi benliğe ulaştıracak tek yoldur. Bir şeyi idrak ettiğimizde, bununla alakalı düşüncemizi açıkladığımızda veya irademizi kullandığımızda benliğimizle baş başa oluruz. Benliğin hayatı bir gerginlik durumudur. Benlik bu gerginliği, kendi çevresine nüfuz etmek veya ondan etkilenmek amacıyla yaratmıştır. Benlik, karşılıklı saldırıların yapılmakta olduğu arenanın dışında kalmaz aksine, bu arenada yön veren bir enerji olarak durur ve kendi tecrübesiyle şekillenir, gelişir (İkbâl, 2014: 124).

Benliğin niteliği, bir ruh veya beden ikiliğinden ziyade bir eylem olarak belirmektedir. İnsanın tecrübesi onun eylemlerinin bir dizisidir. O hâlde, "bizim tüm realitemiz yönelimsel tutumumuzda, karakterimizde ve davranışlarımızda yatar. Beni, mekânda bir şey veya zamâna ait düzen içinde bir takım tecrübeler olarak idrak edemezsiniz. Beni, hükümlerimle, iradi tutumlarımla, amaçlarımla ve emellerimle yorumlamalı anlamalı ve takdir etmelisiniz" (İkbâl, 2014: 125). İkbâl, ruh ve bedeni fiilde birleştirir. Yani yaptığım bir hareket bölünmez, emsalsiz ve tektir. Ego dediğimiz şey ise hareketlerimizin birliğidir. Hareketlerin bölünemezliği, ruh ile beden farkını ortadan kaldırmamakla birlikte onları birbirine yakın hâle getirir. 


\section{Benliğin Metafizik Yorumu}

Benlik, kendi çevresini bir sebep-netice sistemi olarak gördüğünden kendi çevresini anlamak ve ona bağlı yaşamak zorundadır. Ego, kendi çevresini anlayıp kendi tasarrufu altına alır ve bu şekilde hürriyetini elde eder, genişletir. Böylece, egonun faaliyetindeki yol gösterici ve yönlendirici kontrol unsuru, onun müstakil, şahsi bir illiyet olduğunu açıkça ortaya koyar. Ego, Nihai Hakikat veya Nihai Ego'nun hayat ve hürriyetini paylaşır (İkbâl, 2014: 130).

Egonun yönlendirici tutuma sahip olması, onun kaderin hükümleri altında ezilen bir şahsiyet olmadığının da işaretidir. Şöyle ki, kendi hürriyetini elde eden ego, Nihai Ego'nun da hürriyetini paylaşarak aynı zaman da kendi iradesini ortaya koyar. Böylelikle ego, kaderin hükmettiği değil, kadere hükmeden rolünü üstlenir.

Denizinde firtına neden yok senin?

Ey Müslüman sen neden benliksizsin?

Yaratıcının kaderinden şikâyet abes;

Sen neden bizzat yaratıcının kaderi değilsin? (İkbâl, 2013b: 271)

Şiirde, benliğini güçlendirmenin önemine dikkat çekilerek, kadere teslim olmaktansa kadere hükmedilebileceği dile getirilmiştir.

Câvitnâme’de ise şöyle der;

Bizim işimiz ümit ve korkudan başka bir şey değildir, tam bir teslime herkesin himmeti yetmez.

Ey böyle diyen: olacak bu idi oldu, işler bu idi ve oldu âyinine uydu.

Kaderin manâsını anlamamışsın; ne beni ne Allah'1 görmemişsin (İkbâl, 2000: 240).

Kader, kişinin içinde bulunan istidatlarının farkına varması ve bunlarla yaşamına çizilen seçeneklerde tercih yapmasıdır. Kuşkusuz bireyin iç yeteneği kendini geliştirmesiyle kuvveden fiile dönüşür. O hâlde, İkbâl'in sözünü ettiği benliğini geliştirerek Mutlak Ego'ya erişmek, aslında bireyin potansiyel olarak taşıdığ yetenekleri açığa çıkarmasıdır. Bu durumda yapılması gereken şey ise, kişinin benliğe dönmesi ve kendi potansiyelinin farkına varmasıdır. 
İkbâl'e göre, "kim dinamik aşkın imkânları ölçüsünde kendi egosunu kuvvetlendirir ve bu ölçüler içerisinde hareket ederse, o kimse kendi kaderini tayin eder" (Schimmel, 2007: 75).

Benliği güçlendirerek kadere bile hükmeden insan, başkasına muhtaç olmakla benliğini zayıflatır.

Birisine ihtiyaç arz edip bir şey istemekten benliğin cüz’leri dağılır.

Benlik Tur-1 Sina'sının ağacında tecelli nuru görünmez.

Kendi bir avuç toprağını dağıtıp saçma. Ay gibi rızkını kendi vücudundan yontup çıkar.

Hak'tan himmet iste, felekle mücadele et. İslâmiyet'in şerefini ayaklar altına alma (İkbâl, 2005: 40).

İkbâl, benliğin güçlenerek Mutlak Ben'e yakın olma ölçüsünde değer ve azamet kazandığını söyler ve bunun bir yolunu da ilâhi aşka bağlar. Böylelikle benliğin tasavvufi manâda bir feyzle güçlenebileceğinin altını çizer.

İkbâl, doktora çalışması esnasında vahdet-i vücûd felsefesine ve mutasavvıflara büyük ilgi duymuştur ${ }^{1}$. Ancak daha sonra İmam-1 Rabbâni'nin vahdet-i şuhûd görüşünü benimsemiştir. Ona göre, İbn Arabî’nin düşüncesi benliği hiçe sayarak Müslümanları ibadetten ve duadan uzaklaştırıp tembelleştirir. Bir örnekle İbn Arabî'nin bu konudaki düşüncesine bakacak olursak;

O olmayınca bulamadım yolu Hakk'a

Orada oldum Hakk’la diri, buldum beka

Kendimi, kendim yitirdim; yine bulam kendimi

Hep olursun, hiç edince kendi kendini (Arabî, 2000: 40-41).

Şiirde Arabî, benliğini yok eden kişinin Hakk'a ulaşabileceğini yani sonlunun sonsuzda kaybolmasıyla birlikte benliğin nihai amacına ulaşabileceği dile getirilmiştir. $\mathrm{Bu}$ düşünce, İkbâl'in benlik felsefesinin tam zıttı gibi görünmektedir. Onun

\footnotetext{
${ }^{1}$ İkbâl doktora tezi olan ve Türkçe'ye 'Íslâm Felsefesine Bir Katkl' olarak çevrilen kitabının özellikle Sûfi Metafiziğinin Değişik Veçheleri başlı̆̆ı altında Mevlânâ Celâleddin-i Rûmî, Hallac-1 Mansûr gibi mutasavvifların düşüncelerine yer verir. Ayrıca Nur ya da Fikir Olarak Hakikat başlığı altında da İşrâkî felsefenin temsilcisi olan Şeyh Şehabeddin Sühreverdi ve vahdet-i vücûd felsefesinin temsilcisi Muhyiddin İbn Arabî’nin düşüncelerine yer vermiştir. Bkz. Muhammed İkbâl, İslâm Felsefesine Bir Katkl (İran'da Metafizik İlimlerin Tekâmülü), Çev. Cevdet Nazlı, 1995, İstanbul, İnsan Yayınları.
} 
düşüncesinde, benlik her ne kadar Mutlak Ben'e yakınlaşsa da O'nda yok olmaz. Çünkü o, imanda inanan ve kendisine inanılan ikilisini gerekli görür. İkbâl vahdet-i vücûd düşüncesinin Tanrı ile kul arasındaki ontolojik mesafeyi iyi açıklayamadığını düşünerek vahdet-i şuhûd düşüncesini kendine daha yakın bulur. Benlik düşüncesini de kendisine önder kabul ettiği Mevlânâ'ya gönderme yaparak açıklar.

Mevlânâ'ya göre, Hakîkat sırf ruhtur. Ama tabii ki ruhun çeşitli dereceleri vardır. Ben Mutlak Hakîkat'i bir ego veya benlik olarak düşlüyorum. Mutlak Ego'dan ancak egolar doğar. Dünya, madde atomu dediğimiz mekanik hareketten insan kişiliğindeki serbest fikir hareketine kadar, bütün ayrıntılarıyla, Mutlak Benlik'in kişiliğinin belirtisidir. Benliğin niteliğinin ortaya çıkışında dereceler vardır. Vücûd gamının, başından sonuna kadar benliğin giderek tizleşen nağmesi, insan kişiliğinde kemâlini buluncaya kadar yükselir. Bundan dolayıdır ki, Kur'ân'da Mutlak Hakîkat insana şah damarından daha yakındır (Kaf, 50/16), diye buyurulmuştur (İkbâl, 1984: 102-103).

“İkbâl'in benlik felsefesi, kişinin kendi zâtını bilmesi, hissetmesi ya da salahiyetlerinin (yetkilerinin) farkına varmasıdır. Bundan maksat da, kişinin Tanrı'nın kendisine ne gibi kabiliyetler ihsan ettiğini ve onlardan nasıl yararlanabileceğini ve bunların yardımıyla kendi milleti ve belki bütün insanlığın gelişimi ve refahı için neler yapabileceğini bilmesidir. $\mathrm{Bu}$ da insanın kendisini tanıması ve kendisine güvenmesiyle mümkündür” (Çelik, 2004: 125).

İkbâl'in düşüncesinde egonun gerçek amacı Tanrı'ya ulaşmaktır. Yani Tanrı'yla doğrudan ilişki kurabileceği dini tecrübeyi yaşamaktır. İkbâl, insanın Mutlak Hakîkat'e olan yakınlığını şöyle dile getirir;

Ne Kâbe'ye sığarsın, ne puthaneye gelirsin.

Lâkin seni yana yana isteyenlere yana yana koşarsın!

Sana hasret çekenlerin canının içine pervasızca ayak bas.

Sen ev sahibi değil misin? Niçin hırsızlar gibi gizli gizli geliyorsun?

Ey canımdan daha yakın olan, fakat göze görünmeyen sevgili!

Senin hicranın bana başkalarının visalinden (kavuşma) daha güzeldir (İkbâl, 1971: 115,117).

Biz seni arıyoruz, sen gözden uzaksın 
-hayır, yanlış: Biz körüz ve sen hazır bulunuyorsun (İkbâl, 2000: 12).

Benliğin Tanrı'yla olan ilişkisini de bu bağlamda yorumlayabiliriz. Nitekim anladığımız kadarıyla, atomdan insana kadar her varlıkta bulunan benliğin asli görevi kemâle erişmektir. İnsanın kemâle erişmesi de benliğini güçlendirmesi ve Tanrı'ya ulaşma isteğidir. Yani benlik, insanın Mutlak Hakîkat'e varması için bir araçtır. O'nunla olan tüm ilişkisini benlik aracılığıyla kurabilir.

İkbâl'e göre, "Nefsini bilen Rabbini bilir" hadis-i kutsisinden hareketle benliğin en önemli özelliği, benliğini bilmek ve onun şuurunda olmaktır. Benliğini bilen insan hiçbir müşkülattan çekinmez, acı olan bile ona tatlı gelir. Vücûd kalıplarının da çerçevesinden kurtularak kendisine nasip olanı kendi kuvvetiyle bütün âlemden söküp alır (Kılıç, 2013: 188).

İkbâl, benliğin önemini şöyle vurgular;

"Benliğinden haberi olan kullar

Zarardan bile kazanç çıkarırlar" (İkbâl, 2014: 214).

"Yaşam bir sedef ve benlik nisan damlası

O damlayı cevhere dönüştürmeyen sedef işe yarar mı?

Eğer benlik kendini bilir, geliştirir ve kendini korursa

Elde edersin ecelin gelmesi ile dahi ölmeme imkânını" (İkbâl, 2015: 28).

Bu açıdan bakıldığında İkbâl'in düşüncesinde oldukça merkezi bir yer işgal eden ben kavramı birisi ahlâki diğeri metafizik olmak üzere iki anlama gelir. Metafizik anlamda ben, her bireyin emsalsizliğini, biricikliğini, tekliğini tesis eden tanımlanamaz bir benlik duygusu iken, ahlâki ben, hayatta kendine güvenme, kendini tasdik etme, kendine saygı duyma ve ölüm karşısında bile hakikate yapışmayı elden bırakmama, doğru yoldan ayrılmamadır (Gündoğdu, 2013: 166).

İkbâl, benliğin Mutlak Ego’ya ulaşmasının iki yolla mümkün olduğunu düşünür. Ona göre, Hakîkat'in müşahade edilen ve edilemeyen tarafları vardır. Bu anlamda o, insanın bilme yetileri ile evrenden hareketle Mutlak Hakîkat'in simgesel olarak öğrenilebileceğini belirtmektedir. Hakîkat'in müşahade edilen tarafına akılla erişilebilirken müşahade edilemeyen tarafına ise dini tecrübeyle ulaşılabilir.

Duyu, gözlem ve düşünce, bize Tanrı'yı dolaylı olarak takdim edebilir. Çünkü akıl ve duyu, doğası gereği hakîkati parçalara bölerek idrak eder, bu da hakîki olan ile kendileri arasına kaçınılmaz olarak bir perde örer. Oysa dini tecrübe, bize, Mutlak 
Hakîkat'i aracısız olarak bilmemizi sağlar. Dolayısıyla ona göre, gerek Sonsuz Ben’in ve gerekse sonlu benlerin dini tecrübeden hareketle gerçek anlamda bilinmesi, Bergson’cu bir sezgi ile mümkündür (Peker, 2013: 46).

Öyle görünüyor ki, İkbâl'in açıkladığı düşüncede akıl, duyulur olanları görüp müşahade ederken; asıl hakîkat, dini tecrübe ile edinilir. Sonsuz Ben de kendini ancak bu yolla gerçekleştirebilir. Hakîkati anlamak imanın gücüyle mümkün görünmektedir.

Batıda benzer düşünce Kierkegaard'da görülebilir. Kierkegaard bu noktada, Tanrı'nın birey onu tam olarak anlayabilsin diye bireyle eşitlik temelinde olmak istediğini söyler. $\mathrm{Bu}$ eşitlik aslında mutlak farklılığı (Tanrı-insan farklılığı), mutlak eşitlikle iptal etmek isteyen bir paradokstur (Kierkegaard, 2017a: 44). Nihayetinde bu paradoks akıl-iman paradoksunun da bir formudur. Akıl, mutlak farklılığın bilincinde iken aynı anda mutlak eşitliği de kavrayamaz. Bu paradoks ancak imanın gücüyle açıklanabilir. Kierkegaard bu yolla hakikate ulaşmada imanın gerekliliğinin altını çizer ve Tanrı-insan arasında eşitlik derecesine kadar bir iletişimin mümkün olabileceğini düşünür. O hâlde "Hegel'in dinsel imanı akılcı bir sisteme yerleştirme çabası da işe yaramaz görünür” (Carlisle, 2006: 110). Bu anlamda Kierkegaard, Hegelci felsefeye ve özellikle de onun akılsal düşüncesinin dinsel inançtan daha bütünlüklü bir hakikat anlayışını temsil ettiği iddiasına karşı çıkar ve bu yorum İkbâl için de geçerli sayılabilir.

İkbâl, Kur'ân'dan verdiği örneklerle (Bakara, 2/164; En'am, 6/97-99; Rûm, 30/22, 23; Ğ'aşiye, 88/17-20) tabiatın incelenmesi ve bu konuda derin derin düşünülmesi gerektiği fikrinin bizde tabiatın, hakîkatin bir simgesi olduğu konusunda şuur uyandırma çabası olduğunu söyler. Ona göre, Kur'ân'da genellikle tecrübeye önem verilmiştir ve biz bu tecrübeler sayesinde hem hayatımızı zenginleştirebiliriz hem de ufkumuzu genişleterek keskin görüşler elde edebiliriz (İkbâl, 1984: 32-33).

İkbâl, benliği fark etmenin ve ona ulaşmanın yolunun yine bu tecrübelerden geçtiğini söyler. Dolayısıyla ona göre,

Benlik, tecrübenin dışında değildir. İç tecrübe, benliğin işbaşında olması hâlidir. Bir şeyi idrak ettiğimizde, bununla ilgili düşüncemizi açıkladığımızda veya irademizi kullandığımızda benliğimizle baş başa oluruz. Bunu temele alarak, beni hükümlerimle, irâdi tutumlarımla, amaçlarımla ve emellerimle yorumlamalı, anlamalı ve takdir etmelisiniz (İkbâl, 1984: 142, 144). 
Burada benin oluşum süreci kişinin iradesine, amaçlarına ve tutumlarına bağlanmıştır. Yani şuurlu tecrübe olarak tarif ettiği bilinç hâlidir. Bu bilinç, insanın akı1 yoluyla elde ettiği deneyimlerdir.

Hakîkat'le ilişki kurmanın yolu, gözlem ve düşüncelere dayalı tecrübeler dışında bir de his ve idrak aracılığıyla olur. İnsan doğayla ilişkisi esnasında, doğayı yönetme gücünü haksız bir hâkimiyet bağlamında kullanmaktan ziyade manevi hayatta özgür bir şekilde gelişmek için kullanmalıdır. Bu bakımdan insan, ilham yoluyla Hakîkat'e ulaşır. Bunun için Kur'ân'da Secde Sûresi 32/7-9. âyetlerde² sözü geçen kalbe ihtiyaç vardır. Kalp, Kur'ân'a göre her şeyi görür ve kalbin bildirdikleri tam anlamıyla yorumlanırsa asla yanlış sayılmaz. Bu ise, Hakîkat'le uğraşmanın bir yolu sayılmalıdır (İkbâl, 1984: 33-34).

Buradan anlaşılacağı üzere, hakîkate varmak için hem şuurlu tecrübelerimize hem de mistik tecrübelerimize başvurmak bakımından iki yol mevcuttur.

Şuurlu tecrübelerimiz Hakîkat'i uzaktan gözlerken mistik tecrübelerimiz Hakîkat'le daha yakın bir temas içinde olmak ister. Biri teori, diğeri ise yaşanan bir tecrübedir, bir yakınlık, bir kaynaşmadır. Bu konuda başarılı olabilmek için, dinin dua ve ibadet diye adlandırdığı zihnî bir atılımda bulunması gerekir (İkbâl, 1984: 90).

Bu bize hakîkatin bizden ayrı bir yerde değil aksine bizim şuurumuzla dâimi bir birlik içinde olduğunu gösterir. $\mathrm{Bu}$ açıdan bakıldığında, Tanrı ve evren birbirinden bağımsız değildir ve evren İkbâl'in dediği gibi Tanrı'nın bir tezahürü ve açılımıdır.

Yine Kierkegaard ile birlikte söylersek; Hakikate ulaşmak isteyen birey kendi içine dönmeli, kendine dönen Tanrı'ya dönmüş olur. İnsanı harekete geçiren imanın verdiği inanma gücüdür çünkü "imanın kendisi fiiliyattır” (Kierkegaard, 2013: 12). Kierkegaard, hakikat terimini kullanırken öznel ile nesneli, içerisi ile dışarısını karşı karşıya getirir. İçe dönüklüğü yitiren kişi, kendisiyle dolaysız ilişki kurma olanağını yitirir (Kierkegaard, 2017b: IX).

İbn Arabî de, içine dön, yalnız dışınla meşgul olma. Çünkü sen cisminle değil, ruhunla insansın sözüyle aynı düşüncenin izini taşır.

Mistik bir yolda ilerleyen insanın amacı, zamâna ait dünyadan, zamansız dünyaya ve ezeliyete geçmek, yani Tanrı'yı doğrudan doğruya kavramaktır. Bu yönüyle

\footnotetext{
${ }^{2}$ Secde Sûresi (32/7-9); “O (Allah) ki, yarattığı her şeyi güzel yapmış ve ilk başta insanı çamurdan yaratmıştır. Sonra onun zürriyetini, dayanıksız bir suyun özünden üretmiştir. Sonra onu tamamlayıp şekillendirmiş, ona kendi ruhundan üflemiştir. Ve sizin için kulaklar, gözler, kalpler yaratmıştır”.
} 
mistisizmin kaynağı, görünen dünyanın üstünde ve ötesinde görünmeyene ilişkin şuurdur. Mistik, ezelî olanı, gerçek hakîkati doğrudan doğruya tecrübe etmeye çalışmaktadır (Çelik, 2004: 104).

Ölümlü yani sonlu varlık olan "insan için dizili olmayan zamâna erişmek en yüksek maksatlardan biridir. Âşık ve ârif, bir ân için bu mutlak zamâna kavuşabilir. Bu ân, İkbâl'in fazlaca zikrettiği 'benim Allah'la bir vaktim var' hadisinde sözü edilen bir vakittir. Bu vakitte insanla Tanrı arasında ne mekân ne zaman ne de melek bulunur. Bu yüzden İkbâl hesabı, sene ve aydan olmayan zamânı bulmaya çağırır insanı"” (Karadeniz, 2013: 467).

Ey bakışı şahinden daha keskin olan (padişah), sana Allah'ın ihsan ettiği bu mülke bir bak.

Bu gördüğümüz şeyi kim bize kader etmiştir? Lâzım olduğu hâlde bulunmayan şey nedir?

Gece ve gündüz bizim tedbirimizin aynasıdır. O gece ve gündüz bizim kaderimizin aynasıdır.

Ey çok gayretli genç, sana söylüyorum: yarın nedir? Bugün ve dünün kızı değil midir?

Bugüne sahip olan insanın etrafında felek firıl firıl döner.

Böyle insan renk ve koku cihanının yüzünün suyudur. Dün, bugün, yarın, onun hükmündedir.

Allah adamı gece ve gündüzlerin sahibidir (sermayesidir). Zira o, kendi bahtının yıldızıdır ${ }^{4}$ (İkbâl, 1976: 55).

\footnotetext{
${ }^{3}$ Söz konusu hadisin tamamı şu şekildedir; "Benim Allah ile öyle bir vaktim vardır ki ne mukarreb bir melek ne de Mürsel bir nebi benimle birlikte o vaktin içine sığmaz”. Hadis olarak nakledilen bu söz sahih hadis kaynaklarında geçmemekle birlikte çoğu âlim tarafından mevzu olarak kabul edilmiştir. Bu söze daha çok tasavvuf âlimleri eserlerinde yer vermiştir; örneğin İmam Rabbâni'nin Mektûbat'inda 175. Mektupta geçer ve İkbâl'in de İmam Rabbâni'yi kendisine mürşid edindiği dönemde bu hadisi öğrendiğini düşünmekteyiz. Bkz. İmam-1 Rabbâni Ahmed-î Fârûkî Serhendî, Mektûbât Tercemesi, Çev. Hüseyin Hilmi Işık, Hakîkat Kitabevi, İstanbul, 2008, s.217.

${ }^{4}$ Aynı şiir A. Metin Şahin tarafından şu şekilde çevrilmiştir;

"Gün, gecen tedbirlerin bir aynası,

Gün, gecen takdirlerin bir aynası.

Söyle ey genç, söyle ki yarın nedir?

Hem bugün, olmuş dünün kız, söylenir!

Bugünün sahibi olmuş kimseye,

Hep felek gelmiş tavaf etsek diye.

O, cihânın renk ve itrın yüzsuyu,
} 
Şiirlerinde s1k s1k zamânın dizgisinden kurtulmak gerektiğine ve kaderin önceden belirlenmiş, dışına çıkılmayan katı bir yazgı olmadığına dikkat çeken İkbâl, insanın sınırlarını aşmasını ve olup biten olaylar karşısında savrulmaması gerektiğini söyler. Her insan kendi potansiyelini fark etmeli ve onu harekete geçirmelidir.

Benliği sıkı sıkı kucaklamak,

Fâniliği beka ile birleştirmektir.

Benliğin benliğe sığması muhaldir,

Benliğin tâ kendisi olmak kemâldir (İkbâl, 2006: 90).

Görüldüğü üzere, insanı küçük bir âlem olarak gören İkbâl için kendi içine dönüp o âlemi keşfeden insanın Mutlak Zât'a erişebileceği sıkça vurgulanmaktadır. Bu düşünce bize Kur'ân-ı Kerîm'de geçen “Andolsun, insanı biz yarattık ve nefsinin kendisine fisıldadıklarını biliriz ve biz ona şah damarından daha yakınız" (Kaf, 50/16) âyetini hatırlatmaktadır. Dolayısıyla İkbâl'e göre, bize şah damarımızdan daha yakın olan yaratıcıyı kendi içimizde ve benliğimizde aramak, ebedileşmek için doğru bir yol gibi görünmektedir. İkbâl;

Zayıflar kendilerini Tanrı'nın varlı̆ı̆ında kaybederler;

Güçlüler ise kendi varlıklarında O'nu keşfederler (İkbâl, 2007b: 72)

diyerek insanın Mutlak Hakîkat'i bulmasında benliğin önemini vurgular. İkbâl, "insan âlemin ruhudur; âlem ise cesettir. Bunların toplamı âlemi yapar ki o da büyük bir insandır. Eğer yalnız olarak bu âlemi insansız, düşünecek ve bakacak olursan, onu ruhsuz, düzgün yapılı bir ceset olarak görürsün. Cesedin ruhla kemâle erdiği gibi âlemin kemâli de insanla olur” (Arabî, 1977: 234) diyen İbn Arabî’yle aynı görüşü paylaşır.

İnsanın ulaşmayı hedeflediği asıl amaç ebediyettir, o da ancak Mutlak Hakîkat'in ebediyetine ulaşmakla mümkündür. Benliğini güçlendiren ve kemâle ermek isteyen insan, ilâhi aşkın ateşiyle yanarak ebediyete ulaşabilir. İkbâl, "bütün âlem aşka secde eder. Akıl sûmenâtının (puthane) Mahmudu aşktır" (İkbâl, 2005: 71; İkbâl, 2014c: 107; İkbâl, 2012: 84) der. Bu beyitte akıl, bir puthaneye aşk ise onu fetheden tarihî bir kişiliğe benzetilmiştir. Puthane, Hindistan'ın batısında bulunan ve Gazneli Mahmud (998-1030) tarafından büyük bir seferle fethedilip putlarının parçalandığı yer olan Sûmenat (Somnat)'a, aşk ise aynı tarihî olayda putları parçalayan Gazneli

Dün, yarın hükmünde, bil sen doğruyu!”. Bkz. Muhammed İkbâl, Misafir, Çev. Ahmet Metin Şahin, Irmak Yayınları, İstanbul, 2007, s.144. 
Mahmud'a bir gönderme olarak yorumlanabilir. Benzer gönderme İkbâl'in başka bir eserinde açıkça görülmektedir;

Kâbe ehli müslüman bile Somnat puthanesi yapmış, bekliyor;

Bunları kırmak için muhakkak Mahmud Gaznevî bekleniyor!

Bunları yaptıracak akıl ve basiretin kılavuzu ilâhi aşktır,

Onsuz şeriat ve din, tefekkür puthanesinden başka nedir? (İkbâl, 1983: 113)

Beyitlerde, hakîkate ulaşmanın yolunu yalnızca aklın rehberliğine bağlayan putlaşmış düşünceyi yıkacak şeyin gönüldeki aşk olduğu anlatılmak istenmiştir.

İkbâl'in insan-1 kâmil düşüncesinde ortaya koyduğu ideale ulaşma fikri, Platon'la da paralellik kurabileceğimiz Sühreverdî Maktul'un tasavvuf düşüncesinde de görülmektedir. Ona göre, "ruh, duyuların etkisinden sıyrılabildiğimizde yükseliyor, nefsâni ve maddî şeylerle meşgul olduğumuzda yine eski hâlini alıyor. Böylece ruh, maddenin kesafetiyle hiçbir gerçeği göremiyor ve karanlıkla ifade edilen maddî nesneler içinde kalıyor. Ruhta duyulardan sıyrılma veya riyazet yoluyla yeniden ulvî âlemin veya vatanın arzusu beliriyor. İçe doğan bir bilgiyi ifade eden ilhamla, asıl vatanı olan ideler veya akıllar âlemine gidilecek yolu ve yoldaki tehlikeleri öğreniyor. İlkin tabii bulanıklıklardan arınmanın şart olduğu, fitrî güçle beraber riyazet bilgisinin lüzûmu dolayısıyla hırs ve alâkalardan sıyrılmanın ve şehvetin engelleyici etkisinin giderilmesi veya kontrol altına alınması yahut terk edilmesi zarurî olmaktadır. Yolculuk esnasında bu ve benzeri tutkulardan sırasıyla vazgeçilecek ve ölümün yakınlığı bilinecektir. Bütün bunlar ilham sayesinde elde edilmektedir” (Sühreverdî, 1987: 214). Sühreverdî’den serimlenen düşüncenin İkbâl'in ilâhi aşkla, nefsin karanlıktan kurtulup Hakk'a ulaşma fikrinin benzerliği görülebilir.

Aynı düşünce Batı'da Nietzsche’nin üstün insan fikrinde işlenir. Nitekim İkbâl, bazı eserlerinde Nietzsche'ye göndermelerde bulunarak ondan etkilendiğini bize düşündürmektedir. Özellikle onun insan-1 kâmili ile Nietzsche'nin üstün insanı birkaç bakımdan benzerlik gösterir. Her iki düşüncede de insanın ulaşmayı hedefleyeceği bir ideal insan belirtilmiştir ve yaşamın amacı da bu ideale dayandırılmıştır. Nietzsche'nin üstün insanı, "yeryüzünün anlamıdır ve insanların hor görüsünün batacağı bir ummandır. İnsan ise, hayvanla üstün insan arasına geçirilmiş bir iptir. İnsanda büyük olan, bir köprü olmasıdır onun, yoksa bir amaç değil; sevilebilecek olan insanda, bir karşıya geçiş ve batış olmasıdır onun” (Nietzsche, 2012: 22-23). Üstün insan ahlâki 
olarak, ahlâkın dışındadır yoksa ahlâksız değildir. Çünkü Nietzsche'ye göre insanlar eşit değildir ve mevcut ahlâk yasası kölelere göre şekillenmiştir. Bu nedenle üstün insanın ahlâkı mevcut ahlâkın dışında ve üzerinde bir yerdedir. Dolayısıyla üstün insan âlemde manevi ve ahlâki bir amaç görmez ve Tanrı'yı inkârdadır. Oysa insan-1 kâmil illâllah'ın bilincindedir. İkbâl, Nietzsche'ye dair birkaç beyit yazmıştır. Örneğin Câvitnâme’de şöyle geçmektedir;

Arkadaşları onun cezbe hâline dair doğru bir fikir edinmemiş, onu mecnun zannetmişler.

Onun sarhoşluğu her camı kırdı, Allah'tan çekildi, kendinden de ayrıldı.

Onun varlığı Kibriya makamı idi; o makam, akıl ve hikmetin ötesidir.

O, Lâ'da kaldı, illâ'ya gitmedi; abduhu makamını bilmeden gitti (İkbâl, 2000: 297-301).

İkbâl, Nietzsche'nin fikri seviyesinin oldukça yükseldiğini fakat geldiği noktada, Tanrı'yı inkârdan öteye geçemediğinden daha fazla ilerleyemediğini düşünür. Başka bir eserinde Nietzsche adlı şiirinde şunları söyler;

İnsanı vücûda getiren unsurların gevşekliğinden canı sıkılan hakîm, daha kuvvetli bir vücut yaratt1.

Frenk diyarına yüzlerce yeni şuriş (kargaşa) ve karışıklık saldı. Sanki şişeci dükkânına bir deli girdi.

Eğer nağme istiyorsan ondan kaç. Onun kaleminden çıkan fikirler gök gürültüsü gibidir.

Garbın gönlüne o neşter sokmuştur; eli salibin (haçın) kanı ile kırmızıdır.

O, Kâbe zemini üzerine puthane bina etmiştir. Kalbi mü'min, dimağı (zihni) kâfirdir.

Kendini o Nemrud'un ateşine yak. Zira İbrahim'in gülistanı ateş üzerinde açmıştır (İkbâl, 1971: 137).

İkbâl, şiirde garbın gönlüne neşter sokmak ve haçın kanını akıtmak sözleriyle, Nietzsche'nin Hristiyanlığın temel savlarına karşı çıkması ve onları yıkma çabasını anlatmaktadır. İkbâl, Nietzsche'nin Tanrı bilincine varamamasını göz önüne alarak insanlara onun fikirlerinden kaçınıp mü'min kalbiyle teslimiyeti önerir. Üstün insandan farklı olarak, İkbâl'in ideal insanı, 'kendi kişiliğini ne ebedilikten ne de Tanrı'nın yolundan ayırmak ister" (Hasan, 2004: 93). Kendini bu yola adayan insan, her dâim 
Mutlak Varlık'la bir olmak ve O'na ulaşmak ister. Onun bu isteğinin temeli ise, gönlündeki ilâhi aşktır. Ancak o ilâhi aşk sayesinde zaman ve mekânın ötesine geçebilir ve bu sebeple hakîkate ulaşabilir.

İkbâl'e göre, evrendeki hiçbir bilgi Tanrı'yla ilişkilendirilmeden tam mânâsıyla kavranamaz. Bundan ötürü her şey yaratıcısıyla arasındaki organik bağ göz ardı edilmeden düşünülmelidir. İkbâl bu anlamda Hegel'i de eleştirir ve onun düşüncesinin hayâlde kaldığını, yere basmadığını düşünerek şu dizeleri yazar;

Hegel'in istiridyesi incisizdir;

Onun büyüsü tamamen hayâlidir.

Yaşam daha da güçlü nasıl olur?

Benlik nasıl dünya bağından kurtulur?

Sendeki tutkunun ateşi sönmüş hâlde

Gönlü aydınlatan o noktayı benden dinle.

Aklın sonu huzursuz kalmaktır,

Felsefe yaşamdan uzaklaşmaktır.

Fikirlerdeki o sessiz melodiler,

Amel tutkununun ölümüdür.

Din, hayat ülküsünü güçlendirir,

Din, Muhammed ve İbrahim gizidir (İkbâl, 2013a: 25-26).

İkbâl burada, Hegel'in organizm fikrinin, evrenin bir yaratıcı güce dayandırılmadan temellendirilmesinin hayâli bir felsefe olduğuna dikkat çekmiştir. Nitekim aklın sonu huzursuzluktur derken bize, evrendeki asıl gerçekliğin yalnızca akılla kavranamayacağını düşündürüyor.

Ayrıca onun hayâli felsefesini alaya alarak şunları söyler;

Her ne kadar düşüncesinin bâkir kızı gelinler gibi süslenmişse de; onun akla istinat eden (güven veren) felsefesi duygu ile bir araya gelmedi.

Onun felâketlerle cevelân eden aklının kuşu, nedir biliyor musun? O kuş, bir tavuktur ki, şehvetin baskısıyla horoza yaklaşmadan döl alır (İkbâl, 1971: 140). 
Şiirde Hegel'in düşüncesinde akıl ile duygunun bir araya gelmediğini dolayısıyla tinin Mutlak Varlık'la bir ilişkisinin olmamasına işaret edilmiştir. Böylelikle yaratmanın, zamânın ve benliğin ebediyetle olan bağı tam manâsıyla açıklanamamıştır, bu nedenle bu teori İkbâl tarafindan hayâli olarak değerlendirilmiştir. İkbâl, Hegel'i bu şekilde eleştirirken aklın Hakîkat'i müşahade etmedeki yetersizliğini göstermeye çalışır ve bu eksikliğin kişideki sezgi ile tamamlanabileceğini düşündürür. Bu fikrini ise, Hegel ile Mevlânâ’nın kendisinde nasıl bir etki bıraktığını söyleyerek anlatır.

Bir gece tefekkür tırnağı ile Alman hakîminin düğümlerini çözmeğe çalşııyordum.

O Alman hakîmi ki, tefekkürü ile (ebedî) üzerindeki zaman elbisesini çıkarıp atmış, onu çırılçıplak ve apaçık bir hâle getirmiştir.

Hayâlinin genişliği önünde dünya, darlığından utanç duymuştur.

Onun denizine dalınca akıl gemisi tufana tutuldu.

Sanki büyülenmiş bir uykuya daldım. Bâki ve fầniden gözümü yumdum.

Aşk bakışı daha keskinleşti. O anda ilâhi ihtiyar (Mevlânâ) bana göründü.

O bir güneştir ki, tecellisinden Rûm ve Şam aydınlanmıştır.

Bu mayası karanlık cihanda onun alevi çölde perhiz tutanların mumu gibidir.

Onun sözünden mânâ, gelincikler gibi fişkırır.

Bana: ne uyuyorsun kalk dedi; bir seraba gemi sürüyorsun!

Aşk yolunda akılla mı yürüyorsun?

Güneşi mumla mı arıyorsun? (İkbâl, 1971: 138)

İkbâl, Hegel'in fikri düşüncesinin çok ilerlediğini fakat onun düşüncesiyle yola çıkıldığında bir noktadan sonra aklın rehberliğinden çıkıp hayâl dünyasına kapıldığını söylemektedir. $\mathrm{O}$, bu noktada ona Mevlânâ'nın önderlik ettiğini ve aklın düştüğü karanlıktan onun düşüncesiyle kurtulduğunu söyler. Buradan anlayabiliriz ki, onun sezgi diye bize anlattı̆̆ şey, tasavvuf düşüncesindeki aşk fikridir. İkbâl, aşk yolunda akılla yürünemeyeceğini söyleyerek, Hegel'in asıl gerçekliğe ulaşamamasının nedenini, ilâhi aşkın eksikliğine dayandırmış gibi görünüyor.

Yine İkbâl'in dizeleriyle söylemek gerekirse;

İlimde aşk olmazsa, batıl bir ilim olur

Aşk varsa ilimde, ilâhi kimliğe kavuşur

Sevgisiz ilim ve hikmet, birer ölü 
Ak1l bir ok, kaybetmiş yönünü

Aç körün gözüne göster Hak cemâlini

Hz. Ali hâline getir Ebû Leheb’i! (İkbâl, 2014b: 96)

Şair, aklın hedefe varması için aşka ihtiyaç duyduğunu ve aşksız ilmin kör bir göze benzediğini belirterek, ilmin değerini Tanrı'yla arasındaki ilişkiye bağlamıştır.

\section{Sonuç}

İkbâl'in ben dediği kavram, her varlık mertebesinde bulunur ve en yüksek seviyesine insanda ulaşmıştır. Onun benleri Leibniz'in monadları gibi birbirine kapalı görünmemekte aksine birbiriyle etkileşim hâlindedir. Benin mahiyeti ise, ruh ve bedenin ortak faaliyeti olan eylemler bütünüdür. İkbâl, insanı yalnızca ruh ve beden ikilisi olarak görmeyip onun geçmiş tecrübelerine dayandırdığg şuurlu tecrübesini de önemli bir özellik olarak ortaya koyar. Ben dediği kavram şuurlu tecrübenin iş başında olması hâlidir. İnsan şuurlu tecrübesiyle zamanı algılar, anlamlandırır ve kendini bu zaman içinde ortaya koyar. Geçmişi hatırlayarak, şimdide karar vererek geleceği ise hayal ederek yaşar. Tüm bunlar insanın benini ortaya koyan esas durumlardır.

İkbâl, benin yönlendirici tutumu sayesinde insanın şahsi bir kimlik kazandığını ve benliğin gücü ölçüsünce özgür olduğunu düşünür. Bu özgürlük beni, kaderin zincirinden kurtarıp hür iradeye sahip kılar. Böylelikle ben, Mutlak Ben'in yaratıcı hürriyetini paylaşır ve Mutlak Ben'in yeryüzündeki temsilcisi olmayı başarır. Ben, böylelikle metafiziksel bir anlam kazanır ve insanın Mutlak Hakîkat'e ulaşmasında önemli bir rol oynar.

İnsanın bu dünyadaki asıl amacı ebediyete ve mutlak olana erişmektir. Onu bu yola götürecek olan da şuurlu tecrübesinin yanı sıra dini tecrübedir. Şuurlu tecrübemiz bize hakikatle ilgili kısmi bilgiler verebilir fakat dini tecrübe hakikatle daha yakın temas ve kaynaşma imkânı sunar. Böylelikle insan ebediyete ve Mutlak Hakîkat'e bir an olsun perde aralamış olur. Sonlu benlerin tek gayesi Sonsuz Ben'e ulaşmak olmalıdır. Bunu yapabilmek için de dinin öğrettiği ibadetleri yapmakla birlikte ilâhi aşka da sahip olmak gerekir. İkbâl, bunun için bir mürşide bağlanılması gerektiğini düşünür ve kendisinin Mevlânâ'ya bağlı olduğunu söyler.

İlahi aşkın benliği güçlendirmesi için Mevlânâ'nın yolundan gitmek gerektiğini düşünür. Çünkü insanı önemsemeyen tasavvuf düşünürleri, beni yok etmekle hakikate varılacağını düşünür ve İkbâl bunu şiddetle eleştirir. Beni yok eden bu düşünce, insanı pasifleştirir ve eylemlerinden kaderi sorumlu tutmasına yol açar. Oysa Tanrı, insanı hür 
iradesiyle birlikte yaratmıştır. Bu anlamda İkbâl, insana sahip olduğu tüm değerleri teslim eder ve benliğini geliştiren insanın yeryüzünde Tanrı'nın eli olabileceğini söyler.

\section{Kaynakça}

ARABÎ, Muhyiddîn-i İbn (1977). Fütûhat-ı Mekkiye, Çev. Selâhaddin Alpay, İstanbul: Garanti Matbaacılık ve Neşriyat.

ARABÎ, Muhyiddîn-i İbn (2000). Lübb’ül-Lübb (Özün Özü), Çev. İsmail Hakkı Bursevî, İstanbul: Bahar.

AYDIN, Mehmet S. (2000). İslâm Felsefesi Yazıları, İstanbul: Ufuk Kitapları.

CARLİSLE, Clare (2006). Kierkegaard: A Guide for the Perplexed, New York/London: Continium Int. Pub. Group, (ss. 110-131).

ÇELİK, İsa (2004). Muhammed İkbâl'in Tasavvufí Düşüncesi, İstanbul: Kaknüs.

GÜNDOĞDU, Hakan (2013). İkbâl'in Benlik Felsefesi ve Demokrasi, Hece Aylık Edebiyat Dergisi Muhammed İkbâl Sayısı (S. 193, ss. 164-176).

HASAN, R. (2004). İkbâl'in Düşüncesinde İrade Hürriyeti ve Kader, Çev. A. İ. Demir, Kelam Araştırmaları Dergisi 2 (S. 1, ss. 83-94). Ankara.

İKBÂL, Muhammed (1971). Şarktan Haber (İkbâl'den Şiirler içinde), Çev. Ali Nihat Tarlan, İstanbul: İş Bankası.

İKBÂL, Muhammed (1976). Yolcu, Çev. A. N. Tarlan, İstanbul: Eser Matbaası.

İKBÂL, Muhammed (1983). Cebrail'in Kanadı Çev. Yusuf Salih Karaca, İstanbul: Furkan.

İKBÂL, Muhammed (1984). İslâm'da Dini Düşüncenin Yeniden Doğuşu, Çev. N. A. Asrar, İstanbul: Birleşik.

İKBÂL, Muhammed (2000). Câvitnâme, Çev. Annemarie Schimmel, Ankara: Kültür Bakanlığg1.

İKBÂL, Muhammed (2005). Esrar ve Rumuz Çev. Ali Nihat Tarlan, İstanbul: Sûfi Kitap.

İKBÂL, Muhammed (2006). Yeni Gülşen-i Râz (Kulluk Kitabı içinde), Çev. Ali Nihat Tarlan, İstanbul: Sûfi Kitap.

İKBÂL, Muhammed (2007a). Misafir, Çev. Ahmet Metin Şahin, İstanbul: Irmak. 
İKBÂL, Muhammed (2007b). Yansımalar, Çev. Halil Toker, İstanbul: Kaknüs.

İKBÂL, Muhammed (2012). İslâmî Benliğin İçyüzü Çev. Ali Yüksel, Ankara: Hece.

İKBÂL, Muhammed (2013a). Musa Vuruşu, Çev. Celal Soydan, Ankara: Hece.

İKBÂL, Muhammed (2013b). Hicaz Armağanı, Çev. Celal Soydan, Ankara: Hece.

İKBÂL, Muhammed (2014a). İslâm'da Dini Düşüncenin Yeniden Teşekkülü, Çev. Beste Yılmazoğlu, İstanbul: Araf.

İKBÂL, Muhammed (2014b). Câvitnâme, Çev. Halil Toker, İstanbul: Kaknüs.

İKBÂL, Muhammed (2014c). Benliğin Strları, Çev. Beste Yılmazoğlu, İstanbul: Araf.

İKBÂL, Muhammed (2015a). Şikâyet ve Cevabı, Çev. Halil Toker, İstanbul: Demavend.

İNANÇ, Banu Yazgan; YERLIKKAYA, Eset Ercüment (2012). Kişilik Kuramlarl, Ankara: Pegem Akademi.

KARADENIZ, Abdurrahim (2013). Muhammed İkbâl'in Zaman-Mekân, Ölüm ve Ebedîlik Tasavvuru. Hece Aylık Edebiyat Dergisi Muhammed İkbâl Saylsı (S. 193, ss. 465-468).

KILIÇ, Cevdet (2013). İkbâl'in Mücadelesi ve İslâm Dünyasına Etkileri. Hece Aylık Edebiyat Dergisi Muhammed İkbâl Saylsı (S. 193, ss. 177-204).

KIERKEGAARD, Soren (2013). Meseller, Çev. Osman Çakmakçı, İstanbul: Pinhan.

KİERKGAARD, Soren (2017a). Felsefe Parçalarl Ya Da Bir Parça Felsefe, Çev. Doğan Şahiner, İstanbul: Türkiye İş Bankası.

KIERKEGAARD, Soren (2017b). Kaygı Kavramı, Çev. Türker Armaner, İstanbul: Türkiye İş Bankası.

NIETZSCHE, Friedrich Wilhelm (2012). Zerdüsst Böyle Buyurdu, Çev. Osman Derinsu, İstanbul: Varlı.

PEKER, Hidayet (2013). Muhammed İkbâl'de Tanrı Evren İlişkisi. Uludağ Üniversitesi Illahiyat Fakültesi Dergisi (C: 22, S. 1, ss. 39-55). 
SCHIMMEL, Annemarie (2007). Peygamberâne Bir Şair ve Filozof Muhammed İkbâl, Çev. Senail Özkan, İstanbul: Ötüken Neşriyat.

SERHENDÎ, Rabbân-î Ahmedî Fârûkî (2008). Mektûbât Tercemesi, Çev. Hüseyin Hilmi Işık, İstanbul: Hakîkat Kitabevi.

SÜHREVERDÎ, Şehâbeddin (1987), Filozofların İnançları, Ruhun Yolculuğu, Çev. İsmail Yakıt, Felsefe Arkivi (S. 26, ss. 213-226).

TAŞDELEN, Vefa (2013). Muhammed İkbâl'de Aşkın Ben. Hece Aylık Edebiyat Dergisi Muhammed İkbâl Sayısı (S. 193, ss.26-42).

WHITEHEAD, A. N. (1929). Process and Reality. Newyork: Macmillan Publishing. 